\title{
Impact of HCMV infection on NK cell development and function after HSCT
}

\section{Mariella Della Chiesa ${ }^{1}$, Michela Falco ${ }^{2}$, Letizia Muccio ${ }^{1}$, Alice Bertaina ${ }^{3,4}$, Franco Locatelli, ${ }^{3,4}$ and Alessandro Moretta ${ }^{1}$}

${ }^{1}$ DI.ME.S. Dipartimento di Medicina Sperimentale, Centro di Eccellenza per la Ricerca Biomedica, Università di Genova, Genova, Italy

2 Istituto Giannina Gaslini, Genova, Italy

${ }^{3}$ Dipartimento di Onco-Ematologia Pediatrica, Ospedale Bambino Gesù, Roma, Italy

${ }^{4}$ University of Pavia, Pavia, Italy

\section{Edited by:}

Konrad Krzewski, National Institutes

of Health, USA

\section{Reviewed by:}

Vincent Vieillard, Institut National de la Santé et de la Recherche Scientifique, France

Karl-Johan Malmberg, Oslo University Hospital, Norway

Alec James Redwood, University of

Western Australia, Australia

\section{*Correspondence:}

Mariella Della Chiesa, Dipartimento di Medicina Sperimentale, Università di Genova, Sezione di Istologia, Via G.B. Marsano 10, Genova 16132, Italy e-mail:mariella.dellachiesa@unige.it
Natural Killer (NK) cell function is regulated by an array of inhibitory and activating surface receptors that during NK cell differentiation, at variance with $T$ and $B$ cells, do not require genetic rearrangement. Importantly, NK cells are the first lymphocyte population recovering after hematopoietic stem cell transplantation (HSCT). Thus, their role in early immunity after HSCT is considered crucial, as they can importantly contribute to protect the host from tumor recurrence and viral infections before T-cell immunity is fully recovered. In order to acquire effector functions and regulatory receptors, NK cell precursors undergo a maturation process that can be analyzed during immune reconstitution after HSCT. In this context, the occurrence of human cytomegalovirus (HCMV) infection/reactivation was shown to accelerate NK cell maturation by promoting the differentiation of high frequencies of NK cells characterized by a $\mathrm{KIR}^{+} \mathrm{NKG} 2 \mathrm{~A}^{-}$and $\mathrm{NKG}_{2} \mathrm{C}^{+}$mature phenotype. Thus, it appears that the development of NK cells and the distribution of NK cell receptors can be deeply influenced by HCMV infection. Moreover, in HCMV-infected subjects the emergence of so called "memory-like" or "long-lived" NK cells has been documented. These cells could play an important role in protecting from infections and maybe from relapse in patients transplanted for leukemia. All the aspects regarding the influence of HCMV infection on NK cell development will be discussed.

Keywords: human NK cells, HCMV infection, NKG2C, KIR, hematopoietic stem cell transplantation

\section{INTRODUCTION}

Natural killer (NK) cells represent crucial effectors in innate immune response to viral infections and tumors. NK cell function is regulated by an array of germline-encoded surface receptors, that, upon interaction with their ligands, transmit either inhibitory or activating signals (1-3).

Most human NK cells express inhibitory receptors specific for HLA-class I molecules, including the Killer Ig-like Receptors (KIRs), able to distinguish among different HLA-A, -B, and -C allotypes (4), and the CD94/NKG2A heterodimer, specific for HLA-E (5). These receptors allow NK cells to spare HLA-class $\mathrm{I}^{+}$autologous normal cells and to kill cells in which HLA class I expression is down-regulated (e.g., by tumor transformation or viral infection) or cells expressing non-self HLA class I alleles unable to engage inhibitory KIRs (e.g., in the allogeneic transplant settings).

Activating counterparts of the inhibitory receptors specific for HLA class I molecules can be expressed by NK cells. In particular, activating KIRs, including KIR2DS1, KIR2DS2, and KIR3DS1, are highly homologous to their inhibitory counterparts in the extracellular domain, but are characterized by a short cytoplasmic tail lacking Immunoreceptor Tyrosine-Based Inhibitory Motifs (ITIM). On the other hand, activating KIRs interact with DAP12, an adaptor signaling molecule carrying an Immunoreceptor Tyrosine-Based Activating Motif (ITAM) that can induce NK cell activation (6). So far, the HLA class I specificity of activating KIRs has been clearly demonstrated only for KIR2DS1 and KIR2DS4 (6-8). KIR genes are located on chromosome 19 and are inherited as haplotypes. Two basic KIR haplotypes can be found in the human genome: group A haplotypes, which have a fixed number of genes that encode inhibitory receptors (with the exception of the activating receptor KIR2DS4) and group B haplotypes, which have variable gene content, including additional activating KIR genes $(4,9)$.

Another HLA class I-specific activating receptor is represented by the HLA-E-specific CD94/NKG2C heterodimer. At variance with its inhibitory counterpart CD94/NKG2A, which contains an ITIM in the NKG2A cytoplasmic domain, NKG2C, like the activating KIRs, lacks ITIM and is associated with DAP-12 (9).

Human NK cells mainly differentiate in the bone marrow (BM) from $\mathrm{CD} 34^{+}$hematopoietic stem cells (HSCs) through discrete stages of development. However, recent studies suggest that different sites, such as secondary lymphoid compartments (SLCs) (10), human decidua (11), thymus (12), or fetal and adult liver (13) can be involved in this process. Two main subsets of mature NK cells with distinct functional and phenotypic properties have been described: the $\mathrm{CD} 56^{\text {bright }} \mathrm{CD} 16^{-/ \mathrm{low}}$ and the $\mathrm{CD} 56^{\mathrm{dim}} \mathrm{CD} 16^{+}$ subsets. CD56 $6^{\text {bright }} \mathrm{NK}$ cells typically express high levels of the receptor CD94/NKG2A, but low levels of KIR molecules. They are 
not abundant in peripheral blood, while dominate in SLCs for which they express specific homing receptors. CD56 ${ }^{\text {bright }} \mathrm{NK}$ cells produce high levels of immunoregulatory cytokines, but are poorly cytotoxic. In contrast, the CD56 ${ }^{\mathrm{dim}}$ subset is characterized by high surface expression of KIR receptors, is largely represented in peripheral blood and is highly cytotoxic against tumor and virusinfected targets (14). A recent study shows that CD56 ${ }^{\mathrm{dim}} \mathrm{NK}$ cells may also release high amounts of IFN- $\gamma$ very early after activation (15). In addition, a third subset, characterized by a CD56 ${ }^{-} \mathrm{CD} 16^{+}$ surface phenotype, exists, but is rare in healthy individuals and represents a small percentage of total NK cells. However, expansion of $\mathrm{CD}^{-} 6^{-} \mathrm{NK}$ cells have been described in HIV and HCV chronically infected subjects $(16,17)$ and also in recipients of hematopoietic stem cell transplantation (HSCT) $(18,19)$.

The developmental relationship between $\mathrm{CD} 56^{\text {bright }}$ and CD56 ${ }^{\text {dim }}$ has been long debated; however, recent reports suggest that $\mathrm{CD} 56^{\mathrm{dim}}$ derive from CD56 ${ }^{\text {bright }}$ cells. Thus, it has been shown that in $\mathrm{CD} 56^{\text {bright }} \mathrm{CD} 16^{-}$cells telomeres are significantly longer than in $\mathrm{CD} 56^{\mathrm{dim}} \mathrm{CD} 16^{\text {bright }}$ cells (20). In addition, when CD56 ${ }^{\text {bright }} \mathrm{NK}$ cells were infused in NOD/SCID mice, they progressed toward the CD56 ${ }^{\mathrm{dim}}$ phenotype (21). In line with these observations the first wave of NK cells that reconstitute after HSCT is represented by the CD56 $6^{\text {bright }} \mathrm{NK}$ cell subset. Only later on CD56 ${ }^{\text {dim }}$ NK cells appear in the blood and are initially characterized by high CD94/NKG2A expression. The complete maturation of CD56 ${ }^{\mathrm{dim}} \mathrm{NK}$ cells involve the progressive loss of CD94/NKG2A and the acquisition of combinations of KIR molecules, in order to form a relatively stable repertoire which is mainly genetically determined, but influenced by the HLA class I genotype (4, 22-25). During their late stages of differentiation, $\mathrm{NKG}_{2} \mathrm{~A}^{-} \mathrm{KIR}^{+} \mathrm{CD} 56^{\mathrm{dim}}$ NK cells progressively acquire a CD57 ${ }^{+} \mathrm{CD} 94^{\text {low }} \mathrm{CD} 62 \mathrm{~L}^{\text {neg }}$ phenotype (26-29). In order to become fully competent NK cells have been shown to require recognition of self HLA class I molecules during maturation, a phenomenon referred to as "licensing" or "education" (30-32). However, unlicensed NK cells lacking inhibitory receptors specific for self HLA molecules (either KIR or NKG2A/CD94) do exist, but are hyporesponsive $(31,33)$. Thus, in a self environment the NK cell receptor repertoire will ensure self tolerance as each functional NK cell expresses at least one inhibitory receptor specific for self HLA-I molecules. In contrast, in allogeneic settings, NK cells may kill allogeneic cells expressing HLA-I non-self molecules. The existence of "alloreactive" NK cells can be particularly important in HSCT (34). Since HSCT is a widely employed treatment used to cure malignant disorders such as acute leukemia, these alloreactive NK cells can greatly contribute to the eradication of residual tumor cells (Graft vs. Leukemia effect), prevent Graft vs. Host Disease (GvHD), and improve engraftment by the killing of recipient dendritic cells (DC) and T-cells, respectively $(35,36)$.

\section{NK CELL RESPONSES TO HCMV INFECTION}

Natural killer cells can importantly contribute to immune responses against viral infections. Indeed, in patients with $\mathrm{NK}$ cell deficiency a higher susceptibility to herpesvirus infections has been observed (37-39).

Human cytomegalovirus (HCMV) is a $\beta$-herpesvirus that establishes a lifelong persistent infection (40). In immunocompetent hosts, HCMV infection is usually asymptomatic, but reactivation becomes an important cause of morbidity in primary or acquired immunodeficiencies and immunosuppressed patients particularly in transplant recipients. In healthy individuals both T-cell and NK cells are involved in controlling HCMV infection (41).

During the host-HCMV interplay, NK cells are likely to receive stimuli from infected cells or other immune cells that can modulate their phenotype and function. In particular it has been shown that HCMV is capable of shaping the NK cell receptor repertoire inducing the expansion of an NK cell subset expressing the activating NKG2C receptor. Remarkably, this expanded $\mathrm{NKG}_{2} \mathrm{C}^{+} \mathrm{NK}$ cell subset found in HCMV seropositive individuals is also characterized by a mature phenotype, mostly $\mathrm{KIR}^{+} \mathrm{NKG} 2 \mathrm{~A}^{-}$(42). This finding was observed both in healthy individuals and in patients with different pathological conditions. Indeed, increased proportions of $\mathrm{KIR}^{+} \mathrm{NKG} 2 \mathrm{~A}^{-} \mathrm{NKG}_{2} \mathrm{C}^{+}$ NK cells have been described in subjects who experienced different viral infections, including $\operatorname{HIV}(43,44)$, Chikungunya virus (45), Hantavirus (46), HBV and HCV (47). However, it is conceivable that HCMV infection/reactivation, which may occur in chronically infected subjects, may be responsible for the induction of such NK cell phenotype in these patients. $\mathrm{NKG}_{2} \mathrm{C}^{+} \mathrm{KIR}^{+} \mathrm{NK}$ cell expansions have been described also in congenital immunodeficiencies where this NK cell subset has been proposed to play a relevant role in the resolution of HCMV infection (48). Together, these data suggest that the $\mathrm{NKG} 2 \mathrm{C}$ receptor could play a crucial role in HCMV recognition and in promoting the expansion and/or maturation of $\mathrm{NKG}_{2} \mathrm{C}^{+}$cells, as well as in the control of infection.

The mechanism responsible for the NK cell expansion described is still unclear. It has been suggested that NK cells could be stimulated by HCMV-infected targets, through the heterodimer CD94/NKG2C. In this context, HCMV-infected fibroblasts have been shown to favor the expansion of $\mathrm{NKG}_{2} \mathrm{C}^{+} \mathrm{NK}$ cells, cultured in the presence of either IL-15 or IL-2. MAb-mediated masking of CD94 could inhibit this selective expansion (49). Other studies reported that $\mathrm{NKG}_{2} \mathrm{C}^{+} \mathrm{NK}$ cells can undergo proliferation when co-cultured with HLA-E-transfected 721.221 lymphoblastoid cells $(50,51)$ or $\mathrm{K} 562$ cell lines (46). It is possible that $\mathrm{HCMV}$-infected targets may express ligands interacting with $\mathrm{NKG}_{2} \mathrm{C}^{+} \mathrm{NK}$ cells, thus inducing their activation and proliferation. Remarkably, the signal peptide of the HCMV UL40 protein stabilizes HLA-E expression on HCMV-infected fibroblasts, while other HCMV-derived peptides (including US2, US3, US6, US10, and US11) dampen the surface expression of classical HLA class I molecules (52). These observations suggest that, during the interaction with HCMV-infected cells, the expansion of mature NK cells expressing inhibitory self KIRs could be favored because of the lack of inhibitory interactions with classical HLA class I molecules. Moreover, the stabilization of HLA-E, while favoring the expansion of $\mathrm{NKG}_{2} \mathrm{C}^{+}$cells, would inhibit that of cells expressing NKG2A. This is in line with a recent study showing that a past HCMV infection in healthy individuals is strongly correlated with expansion of $\mathrm{NKG}_{2} \mathrm{C}^{+} \mathrm{NK}$ cells expressing inhibitory self KIRs (i.e., educated NK cells expressing KIRs specific for self HLA class I molecules) (51). 
However, direct evidence for the specificity of NKG2C for HLAE molecules loaded with viral peptides, or for an unknown ligand of either host or viral origin expressed by HCMV-infected cells is missing or limited. It would be important to analyze the peptides that in vivo are bound to HLA-E in HCMV-infected cells and to verify their role in inducing NKG2C-mediated NK cell recognition. In this context, by the analysis of HCMV UL40 sequences isolated from HSCT recipients undergoing HCMV reactivation, it has been shown that UL40 is characterized by a certain degree of polymorphism that could modulate NK cell-mediated recognition of HCMV-infected targets. In particular, some UL40 peptides derived from the signal sequence (i.e., HLA-E-binding peptides) encoded by HCMV isolates, are capable of both inhibiting NK cell lysis by NKG2A engagement and inducing NK cell activation through NKG2C triggering, whereas other forms of UL40 peptides do not stimulate $\mathrm{NKG}_{2} \mathrm{C}^{+}$cells, but are still capable of inducing inhibitory responses via NKG2A (53). Whether such UL40 polymorphisms can affect the expansion of NK cells expressing NKG2C and/or virus clearance in HCMV-infected HSCT recipients is unknown.

Human NK cell responses to HCMV can also be elicited through direct recognition of HCMV virions by NK cells (54). After exposure to HCMV, NK cells become activated and produce IFN- $\gamma$. This anti-HCMV response involves the engagement of TLR2 on NK cells by viral particles and the endogenous release of IFN- $\beta$. However, direct recognition of HCMV is not sufficient to induce stable changes in NK cell receptor repertoire.

\section{HCMV DRIVES NK CELL MATURATION TOWARD HIGHLY DIFFERENTIATED STAGES IN HSCT RECIPIENTS}

The imprinting on NK cell phenotype induced by HCMV infection results particularly dramatic when T-cell immunity is impaired in the infected host, such as in chronically infected HIV patients $(43,44)$, congenitally immunodeficient individuals $(48,55)$ and patients undergoing HSCT.

In this context, two recent studies have shown that HCMV reactivation can promote a rapid NK cell development after umbilical cord blood transplantation (UCBT) $(56,57)$. NK cells achieved a full maturation more rapidly in HCMV-reactivating patients as compared to non-infected ones. In particular, NK cells isolated from HCMV-reactivating patients show low percentages of CD56 ${ }^{\text {bright }} \mathrm{NK}$ cell and high proportions of mature CD56 ${ }^{\text {dim }} \mathrm{NK}$ cells expressing the $\mathrm{NKG}_{2} \mathrm{C}^{+} \mathrm{NKG}_{2} \mathrm{~A}^{-} \mathrm{KIR}^{+}$Siglec-7 ${ }^{-} \mathrm{CD}^{+} 7^{+}$ signature, at variance with non-reactivating patients that display a more immature phenotype (57). NKG2 $\mathrm{C}^{+} \mathrm{CD} 56^{\mathrm{dim}} \mathrm{NK}$ cells were characterized by the expression of self-KIR and displayed full competence in terms of cytolytic activity and cytokine production. The frequency of mature $\mathrm{KIR}^{+} \mathrm{NKG} 2 \mathrm{C}^{+} \mathrm{NK}$ cells persisted and continued to increase after 1 year from HSCT in recipients who reactivated HCMV. This expanded and long-living NKG2C ${ }^{+} \mathrm{NK}$ cell subset is clearly reminiscent of a population of $\mathrm{Ly}_{49 \mathrm{H}^{+}} \mathrm{NK}$ cells which expands in murine CMV (MCVM) infected mice and is responsible for disease clearance through the induction of a "memory-like" $\mathrm{NK}$ cell response. Thus, $\mathrm{NKG}_{2} \mathrm{C}^{+}$ $\mathrm{NK}$ cells, expanding after HCMV infection, could represent the human counterpart of murine "memory-like" NK cells. However, a clear recall response against $\mathrm{HCMV}$-infected targets, mediated by human $\mathrm{NKG}_{2} \mathrm{C}^{+} \mathrm{NK}$ cells, has not been shown yet.

Importantly, in mouse, the $\mathrm{Ly} 49 \mathrm{H}$ receptor has been demonstrated to bind to the MCMV protein $\mathrm{m} 157$ which is expressed by infected cells (58).

The mechanisms lying behind this accelerated maturation and expansion of $\mathrm{KIR}^{+} \mathrm{NKG} 2 \mathrm{C}^{+} \mathrm{NK}$ cells after HSCT are not completely understood. As already discussed, developing NK cells could be stimulated by HCMV-infected targets, possibly through the heterodimer CD94/NKG2C. HCMV infection could exert its influence on NK cell development at different sites and/or stages of maturation (Figure 1). First, NK cell precursors could be stimulated by HCMV while differentiating in the BM where they may interact with cells of the myeloid lineage that can be infected by HCMV and that represent a reservoir of latent virus (41). Second, CD56 ${ }^{\text {bright }} \mathrm{NK}$ cells, that are characterized by the expression of the lymph node homing chemokine receptor CCR7 (59), can reach SLC (e.g., lymph node) and interact with infected antigen-presenting cells, DC, or macrophages, that would promote NK cell differentiation toward more mature CD56 $6^{\mathrm{dim}}$ stages. A third possibility is that circulating CD56 ${ }^{\mathrm{dim}} \mathrm{NK}$ cells could migrate to peripheral tissues (59) (e.g., mucosal tissues) where HCMV infection can affect different cell types (fibroblasts, endothelial cells, epithelial cells) (41). In this microenvironment, NK cells would receive, directly or indirectly, proliferating and maturing signals from infected targets that would drive NK cells toward highly differentiated stages of maturation, characterized by the $\mathrm{KIR}^{+} \mathrm{NKG}_{2} \mathrm{C}^{+} \mathrm{NKG} 2 \mathrm{~A}^{-}$signature. This last scenario better corresponds to in vitro data showing that CD56 $6^{\mathrm{dim}}$ NK cells proliferate in response to HCMV-infected fibroblasts (49). However, it is not clear so far whether this expanded $\mathrm{NKG}_{2} \mathrm{C}^{+} \mathrm{KIR}^{+} \mathrm{NKG} 2 \mathrm{~A}^{-}$Siglec-7 ${ }^{-}$NK cell subset, developed in response to $\mathrm{HCMV}$-derived stimuli, represents a long-living cell subset or is rather continuously replenished by novel mature NK cells.

Remarkably, in HCMV-reactivating patients a unusual $\mathrm{CD}^{-} 6^{-} \mathrm{CD} 16^{+}$Siglec- $7^{-}$NK cell subset was detected (57) that was reminiscent of that described in viremic HIV-infected patients undergoing HCMV reactivation (60). The similarity between $\mathrm{CD}^{-} 6^{-} \mathrm{NK}$ cells found in HCMV-infected UCBT recipients and those present in HIV-infected patients was also confirmed by a marked impairment in functional capabilities. This may be consequent, at least in part, to the low expression on $\mathrm{CD}^{-} 6^{-}$cells of several activating receptors such as NCRs and NKG2D, as also reported in chronically HIV-infected patients. It is conceivable that these hyporesponsive $\mathrm{CD}^{-} 6^{-} \mathrm{NK}$ cells are generated after HCMV infection when T-cell immunity is impaired. The accumulation of these phenotypically aberrant and hypofunctional NK cells could also support the concept that HCMV has a role in immunosenescence (61). However, it should be noted that, in HSCT recipients, the hypofunctional state of $\mathrm{CD} 56^{-} \mathrm{NK}$ cells could be reversed by exposure to exogenous cytokines, such as IL-2. This observation would suggest that the generation of these cells can be consequent to chronic stimulation together with lack of appropriate T-cell responses and cytokine production rather than to an irreversible process of aging induced by HCMV. 


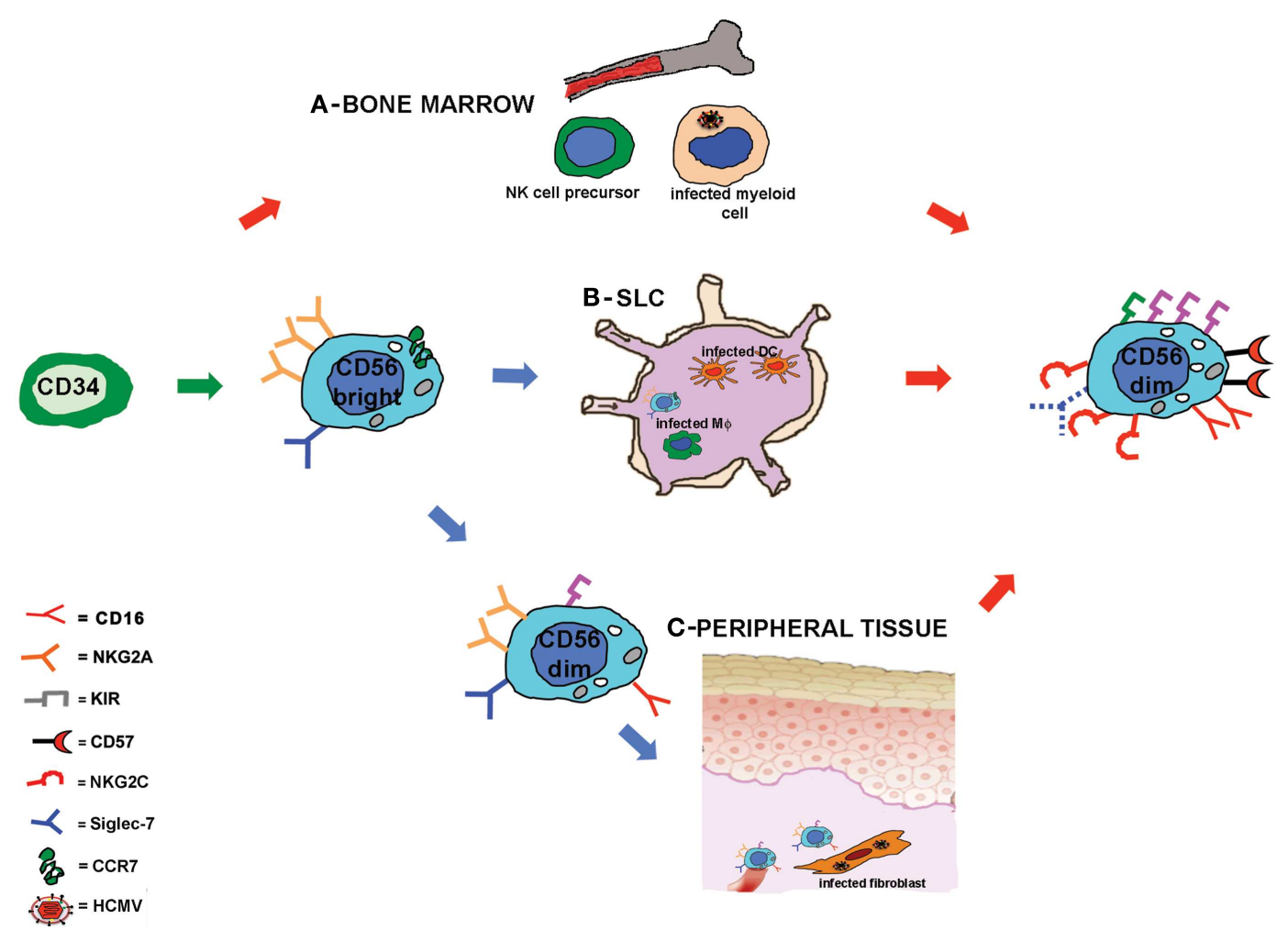

FIGURE 1 | Human cytomegalovirus accelerates NK cell maturation after HSCT: possible sites of NK cell-HCMV interplay. Schematic representation of NK cell maturation from $\mathrm{CD}_{3} 4^{+} \mathrm{HSC}$ in recipients reactivating $\mathrm{HCMV}$. NK cell development is rapidly driven toward a mature stage of differentiation characterized by a $\mathrm{KIR}^{+} \mathrm{NKG} 2 \mathrm{~A}^{-} \mathrm{NKG} 2 \mathrm{C}^{+} \mathrm{CD} 57^{+}$ Siglec- $7^{-}$surface phenotype. The signals driving NK cell maturation might be provided at different developmental stages in different sites: in (A) it is hypothesized that during NK cell differentiation in the bone marrow, NK cell precursors could interact with $\mathrm{HCMV}$-infected myeloid cells; in (B) CD56 bright NK cells that express CCR7 can reach the secondary lymphoid compartment (SLC) where they could interact with HCMV-infected stromal cells, dendritic cells, or macrophages (M $\phi)$; in (C) circulating CD56 dim NKG2A ${ }^{+}$NK cells could migrate to peripheral tissues and interact with HCMV-infected fibroblasts or endothelial cells.
A distinguishing feature of both $\mathrm{CD} 56^{\mathrm{dim}}$ and $\mathrm{CD} 56^{-} \mathrm{NK}$ cells observed in HCMV-infected recipients is the dramatic downregulation of Siglec-7. Although the mechanism/significance of this event is unknown, it represents, together with NKG2C upregulation, the most typical marker of NK cell expansions promoted by HCMV infection. Whether Siglec-7 down-regulation could be a marker of "memory-like" NK cells has still to be investigated.

Human cytomegalovirus-induced NK cell populations with a "memory-like" surface phenotype may contribute not only to the control of virus infection, but also to the protection from leukemia relapses after HSCT. In this context, a recent study reported a correlation between early HCMV reactivation and reduction of leukemia relapse after allogeneic HSCT in adult patients (62). The HCMV-induced rapid maturation of functional NK cells could favor an NK cell-mediated anti-leukemic activity, especially in the case of a KIR-mismatched haplo-HSCT in which the fast differentiation of mature $\mathrm{KIR}^{+} \mathrm{NKG}_{2} \mathrm{~A}^{-}$NK cells could promote the emergence of anti-leukemic alloreactive NK cells.

"Memory-like" NKG2C $\mathrm{C}^{+} \mathrm{NK}$ cells have been also demonstrated to be transplantable employing unmanipulated adult grafts from HCMV seropositive donors (63). These donor-derived NK cells, contained in the graft, expanded not only in recipients undergoing HCMV reactivation, but also in seropositive recipients in the absence of detectable viremia. These $\mathrm{NKG}^{+} \mathrm{C}^{+} \mathrm{NK}$ cells were capable of producing higher levels of IFN- $\gamma$ as compared to $\mathrm{NKG}_{2} \mathrm{C}^{+} \mathrm{NK}$ cells infused in seronegative recipients, suggesting that a subsequent exposure to viral antigens in the recipient can increase cytokine production, by inducing a "memory-like" response that might contribute to control of HCMV reactivation in these $\mathrm{HCMV}^{+}$recipients. Of note, a recent paper suggested that NK cells exposed to multiple cytokines (a circumstance which likely occurs during an anti-viral immune response) can acquire a "memory-like" phenotype and would release higher amounts of IFN- $\gamma$ following restimulation with cytokines or target cells (64).

NKG2C thus seems to play a central role in HCMV-induced responses by NK cells; however, recent reports indicated that also other NK receptors may be involved and that NKG2C could be dispensable. For example, in a cohort of children with or without congenital HCMV infection the deletion of one or two copies of NKG2C did not correlate with a higher incidence of HCMV infection (65). Further supporting the concept that NK receptors other than NKG2C can contribute to shape NK cell receptor repertoire, following HCMV infection, is a study reporting the expansion 
of NKG2 $\mathrm{A}^{-} \mathrm{NKG} 2 \mathrm{C}^{-} \mathrm{NK}$ subsets expressing activating KIRs in a cohort of HCMV seropositive healthy individuals (51). In this context, a number of studies suggested that the presence of activating KIRs is protective against viral infections (66-69).

\section{CONCLUDING REMARIKS}

The development of NK cells reconstituting after transplantation can be profoundly affected by HCMV infection/reactivation, which is a common event in immunocompromised HSCT recipients. Although HCMV infection is cause of morbidity and mortality in such patients, it can also promote NK cell differentiation by accelerating the acquisition of a fully mature $\mathrm{KIR}^{+} \mathrm{NKG}_{2} \mathrm{~A}^{-}$phenotype. Notably, in the case of KIR-mismatched haplo-HSCT, this phenomenon may be of particular benefit, since it results in rapid expansion of alloreactive NK cells (characterized in all instances by the $\mathrm{KIR}^{+} \mathrm{NKG}_{2} \mathrm{~A}^{-}$phenotype). These mature NK cells can display not only anti-leukemia activity but also important antiviral activity that could be beneficial to HSCT recipients. Finally, the strong imprinting induced by HCMV on developing NK cells could be (cautiously) harnessed to design new adoptive NK cell based therapies.

\section{ACKNOWLEDGMENTS}

Supported by grants awarded by Associazione Italiana Ricerca sul Cancro: IG project no. 10643 (Alessandro Moretta) and Special Project 5x1000 no. 9962 (Alessandro Moretta, Franco Locatelli); Ministero dell'Istruzione, dell'Università e della Ricerca (M.I.U.R.); and Progetto Ricerca Ateneo 2012 (Mariella Della Chiesa).

\section{REFERENCES}

1. Moretta A, Bottino C, Vitale M, Pende D, Biassoni R, Mingari MC, et al. Receptors for HLA class-I molecules in human natural killer cells. Annu Rev Immunol (1996) 14:619-48. doi:10.1146/annurev.immunol.14.1.619

2. Lanier LL. NK cell receptors. Annu Rev Immunol (1998) 16:359-93. doi:10.1146/ annurev.immunol.16.1.359

3. Moretta A, Bottino C, Vitale M, Pende D, Cantoni C, Mingari MC, et al. Activating receptors and coreceptors involved in human natural killer cellmediated cytolysis. Annu Rev Immunol (2001) 19:197-223. doi:10.1146/ annurev.immunol.19.1.197

4. Parham P. MHC class I molecules and KIRs in human history, health and survival. Nat Rev Immunol (2005) 5:201-14. doi:10.1038/nri1570

5. Braud VM, Allan DSJ, O'Callaghan CA, Soderstrom K, D'Andrea A, Ogg GS, et al. HLA-E binds to natural killer cell receptors CD94/NKG2A, B and C. Nature (1998) 391:795-9. doi:10.1038/35869

6. Moretta A, Sivori S, Vitale M, Pende D, Morelli L, Augugliaro R, et al. Existence of both inhibitory ( $\mathrm{p} 58$ ) and activatory ( $\mathrm{p} 50$ ) receptors for HLAC molecules in human natural killer cells. J Exp Med (1995) 182:875-84. doi:10.1084/jem.182.3.875

7. Chewning JH, Gudme CN, Hsu KC, Selvakumar A, Dupont B. KIR2DS1-positive NK cells mediate alloresponse against the C2 HLA-KIR ligand group in vitro. J Immunol (2007) 179:854-68.

8. Graef T, Moesta AK, Norman PJ, Abi-Rached L, Vago L, Older Aguilar AM, et al. KIR2DS4 is a product of gene conversion with KIR3DL2 that introduced specificity for HLA-A 11 while diminishing avidity for HLA-C. J Exp Med (2009) 206:2557-72. doi:10.1084/jem.20091010

9. Hsu KC, Liu XR, Selvakumar A, Mickelson E, O’Reilly RJ, Dupont B. Killer Iglike receptor haplotype analysis by gene content: evidence for genomic diversity with a minimum of six basic framework haplotypes, each with multiple subsets. J Immunol (2002) 169:5118-29.

10. Freud AG, Caligiuri MA. Human natural killer cell development. Immunol Rev (2006) 214:56-72. doi:10.1111/j.1600-065X.2006.00451.x
11. Vacca P, Vitale C, Montaldo E, Conte R, Cantoni C, Fulcheri E, et al. CD34+ hematopoietic precursors are present in human decidua and differentiate into natural killer cells upon interaction with stromal cells. Proc Natl Acad Sci U S A (2011) 108:2402-7. doi:10.1073/pnas.1016257108

12. Mingari MC, Vitale C, Cantoni C, Bellomo R, Ponte M, Schiavetti F, et al. Interleukin-15-induced maturation of human natural killer cells from early thymic precursors: selective expression of CD94/NKG2-A as the only HLA class I-specific inhibitory receptor. Eur J Immunol (1997) 27:1374-80. doi:10.1002/ eji. 1830270612

13. Moroso V, Famili F, Papazian N, Cupedo T, van der Laan LJ, Kazemier G, et al. NK cells can generate from precursors in the adult human liver. Eur J Immunol (2011) 41:3340-50. doi:10.1002/eji.201141760

14. Caligiuri MA. Human natural killer cells. Blood (2008) 112:461-9. doi:10.1182/ blood-2007-09-077438

15. De Maria A, Bozzano F, Cantoni C, Moretta L. Revisiting human natural killer cell subset function revealed cytolytic CD56(dim)CD16+ NK cells as rapid producers of abundant IFN-gamma on activation. Proc Natl Acad Sci U S A (2011) 108:728-32. doi:10.1073/pnas.1012356108

16. Mavilio D, Lombardo G, Benjamin J, Kim D, Follman D, Marcenaro E, et al. Characterization of CD56-/CD16+ natural killer (NK) cells: a highly dysfunctional NK subset expanded in HIV-infected viremic individuals. Proc Natl Acad Sci U S A (2005) 102:2886-91. doi:10.1073/pnas.0409872102

17. Bjorkstrom NK, Ljunggren HG, Sandberg JK. CD56 negative NK cells: origin, function, and role in chronic viral disease. Trends Immunol (2010) 31:401-6. doi:10.1016/j.it.2010.08.003

18. Lu X, Kondo Y, Takamatsu H, Ohata K, Yamazaki H, Takami A, et al. CD16+ CD56- NK cells in the peripheral blood of cord blood transplant recipients: a unique subset of NK cells possibly associated with graft-versus-leukemia effect. Eur J Haematol (2008) 81:18-25. doi:10.1111/j.1600-0609.2008.01073.x

19. De Angelis C, Mancusi A, Ruggeri L, Capanni M, Urbani E, Velardi A, et al. Expansion of CD56-negative, CD16-positive, KIR-expressing natural killer cells after $\mathrm{T}$ cell-depleted haploidentical hematopoietic stem cell transplantation. Acta Haematol (2011) 126:13-20. doi:10.1159/000323661

20. Romagnani C, Juelke K, Falco M, Morandi B, D'Agostino A, Costa R, et al. CD56brightCD16- killer Ig-like receptor- NK cells display longer telomeres and acquire features of CD56dim NK cells upon activation. J Immunol (2007) 178:4947-55.

21. Chan A, Hong DL, Atzberger A, Kollnberger S, Filer AD, Buckley CD, et al. CD56bright human NK cells differentiate into CD56dim cells: role of contact with peripheral fibroblasts. J Immunol (2007) 179:89-94.

22. Yawata M, Yawata N, Draghi M, Partheniou F, Little AM, Parham P. MHC class I-specific inhibitory receptors and their ligands structure diverse human NK-cell repertoires toward a balance of missing self-response. Blood (2008) 112:2369-80. doi:10.1182/blood-2008-03-143727

23. Andersson S, Malmberg JA, Malmberg KJ. Tolerant and diverse natural killer cell repertoires in the absence of selection. Exp Cell Res (2010) 316:1309-15. doi:10.1016/j.yexcr.2010.02.030

24. Beziat V, Descours B, Parizot C, Debre P, Vieillard V. NK cell terminal differentiation: correlated stepwise decrease of NKG2A and acquisition of KIRs. PLoS One (2010) 5:e11966. doi:10.1371/journal.pone.0011966

25. Schonberg K, Sribar M, Enczmann J, Fischer JC, Uhrberg M. Analyses of HLAC-specific KIR repertoires in donors with group A and B haplotypes suggest a ligand-instructed model of NK cell receptor acquisition. Blood (2011) 117:98-107. doi:10.1182/blood-2010-03-273656

26. Bjorkstrom NK, Riese P, Heuts F, Andersson S, Fauriat C, Ivarsson MA, et al. Expression patterns of NKG2A, KIR, and CD57 define a process of CD56dim NK-cell differentiation uncoupled from NK-cell education. Blood (2010) 116:3853-64. doi:10.1182/blood-2010-04-281675

27. Juelke K, Killig M, Luetke-Eversloh M, Parente E, Gruen J, Morandi B, et al. CD62L expression identifies a unique subset of polyfunctional CD56dim NK cells. Blood (2010) 116:1299-307. doi:10.1182/blood-2009-11-253286

28. Lopez-Verges S, Milush JM, Pandey S, York VA, Arakawa-Hoyt J, Pircher H, et al. CD57 defines a functionally distinct population of mature NK cells in the human CD56dimCD16+ NK-cell subset. Blood (2010) 116:3865-74. doi:10.1182/blood-2010-04-282301

29. Yu J, Mao HC, Wei M, Hughes T, Zhang J, Park IK, et al. CD94 surface density identifies a functional intermediary between the CD56bright and CD56dim human NK-cell subsets. Blood (2010) 115:274-81. doi:10.1182/blood-2009-04215491 
30. Kim S, Poursine-Laurent J, Truscott SM, Lybarger L, Song YJ, Yang L, et al. Licensing of natural killer cells by host major histocompatibility complex class I molecules. Nature (2005) 436:709-13. doi:10.1038/nature03847

31. Anfossi N, Andre P, Guia S, Falk CS, Roetynck S, Stewart CA, et al. Human NK cell education by inhibitory receptors for MHC class I. Immunity (2006) 25:331-42. doi:10.1016/j.immuni.2006.06.013

32. Brodin P, Karre K, Hoglund P. NK cell education: not an on-off switch but a tunable rheostat. Trends Immunol (2009) 30:143-9. doi:10.1016/j.it.2009. 01.006

33. Cooley S, Xiao F, Pitt M, Gleason M, McCullar V, Bergemann TL, et al. A subpopulation of human peripheral blood NK cells that lacks inhibitory receptors for self-MHC is developmentally immature. Blood (2007) 110:578-86. doi:10.1182/blood-2006-07-036228

34. Moretta L, Locatelli F, Pende D, Marcenaro E, Mingari MC, Moretta A. Killer Ig-like receptor-mediated control of natural killer cell alloreactivity in haploidentical hematopoietic stem cell transplantation. Blood (2011) 117:764-71. doi:10.1182/blood-2010-08-264085

35. Ruggeri L, Aversa F, Martelli MF, Velardi A. Allogeneic hematopoietic transplantation and natural killer cell recognition of missing self. Immunol Rev (2006) 214:202-18. doi:10.1111/j.1600-065X.2006.00455.x

36. Locatelli F, Pende D, Mingari MC, Bertaina A, Falco M, Moretta A, et al. Cellular and molecular basis of haploidentical hematopoietic stem cell transplantation in the successful treatment of high-risk leukemias: role of alloreactive NK cells. Front Immunol (2013) 4:15. doi:10.3389/fimmu.2013.00015

37. Biron CA, Byron KS, Sullivan JL. Severe herpesvirus infections in an adolescent without natural killer cells. N Engl J Med (1989) 320:1731-5. doi:10.1056/ NEJM198906293202605

38. Orange JS. Human natural killer cell deficiencies and susceptibility to infection. Microbes Infect (2002) 4:1545-58. doi:10.1016/S1286-4579(02)00038-2

39. Etzioni A, Eidenschenk C, Katz R, Beck R, Casanova JL, Pollack S. Fatal varicella associated with selective natural killer cell deficiency. JPediatr (2005) 146:423-5. doi:10.1016/j.jpeds.2004.11.022

40. Ho M. Epidemiology of cytomegalovirus infections. Rev Infect Dis (1990) 12(Suppl 7):S701-10. doi:10.1093/clinids/12.Supplement_7.S701

41. La Rosa C, Diamond DJ. The immune response to human CMV. Future Virol (2012) 7:279-93. doi:10.2217/fvl.12.8

42. Guma M, Angulo A, Vilches C, Gomez-Lozano N, Malats N, Lopez-Botet M. Imprint of human cytomegalovirus infection on the NK cell receptor repertoire. Blood (2004) 104:3664-71. doi:10.1182/blood-2004-05-2058

43. Guma M, Cabrera C, Erkizia I, Bofill M, Clotet B, Ruiz L, et al. Human cytomegalovirus infection is associated with increased proportions of NK cells that express the CD94/NKG2C receptor in aviremic HIV-1-positive patients. J Infect Dis (2006) 194:38-41. doi:10.1086/504719

44. Brunetta E, Fogli M, Varchetta S, Bozzo L, Hudspeth KL, Marcenaro E, et al. Chronic HIV-1 viremia reverses NKG2A/NKG2C ratio on natural killer cells in patients with human cytomegalovirus co-infection. AIDS (2010) 24:27-34. doi:10.1097/QAD.0b013e3283328d1f

45. Petitdemange C, Becquart P, Wauquier N, Beziat V, Debre P, Leroy EM, et al. Unconventional repertoire profile is imprinted during acute chikungunya infection for natural killer cells polarization toward cytotoxicity. PLoS Pathog (2011) 7:e1002268. doi:10.1371/journal.ppat.1002268

46. Bjorkstrom NK, Lindgren T, Stoltz M, Fauriat C, Braun M, Evander M, et al. Rapid expansion and long-term persistence of elevated NK cell numbers in humans infected with hantavirus. J Exp Med (2011) 208:13-21. doi:10.1084/ jem. 20100762

47. Beziat V, Dalgard O, Asselah T, Halfon P, Bedossa P, Boudifa A, et al. CMV drives clonal expansion of NKG2C+ NK cells expressing self-specific KIRs in chronic hepatitis patients. Eur J Immunol (2012) 42:447-57. doi:10.1002/eji. 201141826

48. Kuijpers TW, Baars PA, Dantin C, van den Burg M, van Lier RA, Roosnek E. Human NK cells can control CMV infection in the absence of T cells. Blood (2008) 112:914-5. doi:10.1182/blood-2008-05-157354

49. Guma M, Budt M, Saez A, Brckalo T, Hengel H, Angulo A, et al. Expansion of CD94/NKG2C+ NK cells in response to human cytomegalovirus-infected fibroblasts. Blood (2006) 107:3624-31. doi:10.1182/blood-2005-09-3682

50. Guma M, Busch LK, Salazar-Fontana LI, Bellosillo B, Morte C, Garcia P, et al. The CD94/NKG2C killer lectin-like receptor constitutes an alternative activation pathway for a subset of CD8+ T cells. Eur J Immunol (2005) 35:2071-80. doi:10.1002/eji.200425843
51. Beziat V, Liu LL, Malmberg JA, Ivarsson MA, Sohlberg E, Bjorklund AT, et al. NK cell responses to cytomegalovirus infection lead to stable imprints in the human KIR repertoire and involve activating KIRs. Blood (2013) 121:2678-88. doi:10.1182/blood-2012-10-459545

52. Tortorella D, Gewurz BE, Furman MH, Schust DJ, Ploegh HL. Viral subversion of the immune system. Annu Rev Immunol (2000) 18:861-926. doi:10.1146/ annurev.immunol.18.1.861

53. Heatley SL, Pietra G, Lin J, Widjaja JM, Harpur CM, Lester S, et al. Polymorphism in human cytomegalovirus UL40 impacts on recognition of human leukocyte antigen-E (HLA-E) by natural killer cells. J Biol Chem (2013) 288:8679-90. doi:10.1074/jbc.M112.409672

54. Muntasell A, Costa-Garcia M, Vera A, Marina-Garcia N, Kirschning CJ, LopezBotet M. Priming of NK cell anti-viral effector mechanisms by direct recognition of human cytomegalovirus. Front Immunol (2013) 4:40. doi:10.3389/fimmu. 2013.00040

55. Farnault L, Chambost H, Michel G, Thuret I, De Saint Basile G, Fischer A, et al. Persistence of natural killer cells with expansion of a hypofunctional CD56$\mathrm{CD} 16+\mathrm{KIR}+\mathrm{NKG} 2 \mathrm{C}+$ subset in a patient with atypical Janus kinase 3-deficient severe combined immunodeficiency. J Allergy Clin Immunol (2013) 131:1230-3. doi:10.1016/j.jaci.2012.08.047

56. Foley B, Cooley S, Verneris MR, Pitt M, Curtsinger J, Luo X, et al. Cytomegalovirus reactivation after allogeneic transplantation promotes a lasting increase in educated NKG2C+natural killer cells with potent function. Blood (2011) 119(11):2665-74. doi:10.1182/blood-2011-10-386995

57. Della Chiesa M, Falco M, Podesta M, Locatelli F, Moretta L, Frassoni F, et al. Phenotypic and functional heterogeneity of human NK cells developing after umbilical cord blood transplantation: a role for human cytomegalovirus? Blood (2012) 119:399-410. doi:10.1182/blood-2011-08-372003

58. Sun JC, Lopez-Verges S, Kim CC, Derisi JL, Lanier LL. NK cells and immune "memory". J Immunol (2011) 186:1891-7. doi:10.4049/jimmunol.1003035

59. Cooper MA, Fehniger TA, Caligiuri MA. The biology of human natural killercell subsets. Trends Immunol (2001) 22:633-40. doi:10.1016/S1471-4906(01) 02060-9

60. Brunetta E, Fogli M, Varchetta S, Bozzo L, Hudspeth KL, Marcenaro E, et al. The decreased expression of Siglec-7 represents an early marker of dysfunctional natural killer-cell subsets associated with high levels of HIV-1 viremia. Blood (2009) 114:3822-30. doi:10.1182/blood-2009-06-226332

61. Solana R, Tarazona R, Aiello AE, Akbar AN, Appay V, Beswick M, et al. CMV and immunosenescence: from basics to clinics. Immun Ageing (2012) 9:23. doi:10.1186/1742-4933-9-23

62. Elmaagacli AH, Steckel NK, Koldehoff M, Hegerfeldt Y, Trenschel R, Ditschkowski M, et al. Early human cytomegalovirus replication after transplant is associated with a decreased relapse-risk: evidence for a putative virusversus-leukemia effect AML patients. Blood (2011) 118(5):1402-12. doi:10. 1182/blood-2010-08-304121

63. Foley B, Cooley S, Verneris MR, Curtsinger J, Luo X, Waller EK, et al. Human cytomegalovirus (CMV)-induced memory-like NKG2C(+) NK cells are transplantable and expand in vivo in response to recipient CMV antigen. J Immunol (2012) 189:5082-8. doi:10.4049/jimmunol.1201964

64. Romee R, Schneider SE, Leong JW, Chase JM, Keppel CR, Sullivan RP, et al. Cytokine activation induces human memory-like NK cells. Blood (2012) 120:4751-60. doi:10.1182/blood-2012-04-419283

65. Noyola DE, Fortuny C, Muntasell A, Noguera-Julian A, Munoz-Almagro C, Alarcon A, et al. Influence of congenital human cytomegalovirus infection and the NKG2C genotype on NK-cell subset distribution in children. Eur J Immunol (2012) 42:3256-66. doi:10.1002/eji.201242752

66. Cook M, Briggs D, Craddock C, Mahendra P, Milligan D, Fegan C, et al. Donor KIR genotype has a major influence on the rate of cytomegalovirus reactivation following T-cell replete stem cell transplantation. Blood (2006) 107:1230-2. doi:10.1182/blood-2005-03-1039

67. Stern M, Elsasser H, Honger G, Steiger J, Schaub S, Hess C. The number of activating KIR genes inversely correlates with the rate of CMV infection/reactivation in kidney transplant recipients. Am J Transplant (2008) 8:1312-7. doi:10.1111/ j.1600-6143.2008.02242.x

68. Zaia JA, Sun JY, Gallez-Hawkins GM, Thao L, Oki A, Lacey SF, et al. The effect of single and combined activating killer immunoglobulin-like receptor genotypes on cytomegalovirus infection and immunity after hematopoietic cell transplantation. Biol Blood Marrow Transplant (2009) 15:315-25. doi:10.1016/j.bbmt.2008.11.030 
69. Stern M, Hadaya K, Honger G, Martin PY, Steiger J, Hess C, et al. Telomeric rather than centromeric activating KIR genes protect from cytomegalovirus infection after kidney transplantation. Am J Transplant (2011) 11:1302-7. doi:10.1111/j.1600-6143.2011.03516.x

Conflict of Interest Statement: Alessandro Moretta is a founder and shareholder of Innate-Pharma (Marseille, France). The remaining authors declare no conflicts of interest.

Received: 23 September 2013; accepted: 02 December 2013; published online: 13 December 2013.
Citation: Della Chiesa M, Falco M, Muccio L, Bertaina A, Locatelli F and Moretta A (2013) Impact of HCMV infection on NK cell development and function after HSCT. Front. Immunol. 4:458. doi: 10.3389/fimmu.2013.00458

This article was submitted to NK Cell Biology, a section of the journal Frontiers in Immunology.

Copyright (0) 2013 Della Chiesa, Falco, Muccio, Bertaina, Locatelli and Moretta. This is an open-access article distributed under the terms of the Creative Commons Attribution License (CC BY). The use, distribution or reproduction in other forums is permitted, provided the original author(s) or licensor are credited and that the original publication in this journal is cited, in accordance with accepted academic practice. No use, distribution or reproduction is permitted which does not comply with these terms. 